\title{
Integrating ecosystem services and climate change responses in coastal wetlands development plans for Bangladesh
}

\author{
Md. Sarwar Hossain • Lars Hein • Frans I. Rip • \\ John A. Dearing
}

Received: 6 February 2013 / Accepted: 4 July 2013

(C) Springer Science+Business Media Dordrecht 2013

\begin{abstract}
This study explores the integration of ecosystem services and climate change adaptation in development plans for coastal wetlands in Bangladesh. A new response framework for adaptation is proposed, based on an empirical analysis and consultations with stakeholders, using a modified version of the DPSIR (Driver-Pressure-State-ImpactResponse) framework. The framework is tested in the Narail district of Bangladesh, where temperature has increased by about $1{ }^{\circ} \mathrm{C}$ in the summer in combination with an increase in rainfall of $0.70 \mathrm{~mm} \mathrm{day}^{-1} \mathrm{yr}^{-1}$ in the last decade. Calibrated model (MAGICC/SENGEN) projections forecast, on average, a temperature increase of up to $5{ }^{\circ} \mathrm{C}$ and an increase in rainfall of $25 \%$ by the end of this century. Water diversion in the upstream regions of the Ganges River delta contributes to increase water scarcity in the dry season. Enhanced rainfall and the immense pressure of water discharges from upstream water sources are increasing the risk of floods and river erosion in the dry season. An increase in the water holding capacity of rivers, wetlands and canals by dredging is urgently required. The empirical model of this study is intended to support adaptation planning and monitoring in Bangladesh and can be used in other data-poor areas which will suffer from climate change.
\end{abstract}

Keywords Climate change $\cdot$ Ecosystem services $\cdot$ Wetlands $\cdot$ Livelihood . Planning $\cdot$ Monitoring $\cdot$ Adaptation

\section{Introduction}

Bangladesh is one of the most vulnerable nations to climate change due to geographic and climatic features (Maplecroft 2010; Ali 1999). This vulnerability is adding more pressure to the existing problems such as dry season water scarcity and population growth in Bangladesh (ADB 2005). Climate change induced drought has already damaged 1 million tons of food

M. S. Hossain $(\bowtie) \cdot J$. A. Dearing

Geography and Environment, University of Southampton, Southampton, UK

e-mail: koushikadd@yahoo.com

L. Hein • F. I. Rip

Environmental Sciences Group, Wageningen University, Wageningen, The Netherlands 
grains in 1997 and $50 \%$ of food grain was damaged in 1982 by floods. Rice and wheat production is likely to decrease $28 \%$ and $68 \%$ respectively due to a $1-2{ }^{\circ} \mathrm{C}$ increase in temperature (Islam et al. 2011). Moreover, sea level rise (SLR) poses a risk of losses estimated to reach $10 \%$ GDP by the year 2050 (WB 2000).

The United Nations Intergovernmental Panel on Climate Change (IPCC) (2007a) has reported on the possibility of a shift in type and structure of wetland ecosystems due to temperature and rainfall variability. These changes will certainly have consequences for livelihoods because $\sim 80 \%$ of rural households strongly depend on wetland resources (BCAS 2006; Islam 2005; Rahman and Islam 2005). Wetlands contribute around $46 \%$ of all fish consumed in Bangladesh (Ali 1997; DoF 2000).

Increasing population and rural poverty have already done much damage to wetland ecosystems (Rahman and Islam 2005; ADB 2003). Realizing this, there have been significant modifications of floodplain environments since the 1960s. But cost-benefit analysis indicates that most of the projects were not successful because they did not consider the whole socio-ecological system (Rahman and Islam 2005) many misconceived developments created social and environmental conflicts (Ahmed 2011; Hossain and Roy 2010; Islam 2005). Moreover, the coastal area is not only threatened by climate change but also by rising salinity and flood inundation. In this respect, the government has ignored its own National Adaptation Program of Action (NAPA) for designing and implementing a water resource management plan (Hossain et al. 2010). Therefore, development plan draws together livelihoods, ecosystems and climate change is therefore essential.

Adaptation planning for climate change is arguably the key challenge of this century for development in low income countries. Schipper (2007) recommended including adaptation responses in mainstream development planning and a similar policy guideline was proposed by the Organization for Economic Co-Operation and Development (OECD) 2009. It suggested that approaches to planning needed to understand the challenges of climate change, make appropriate adjustments in policy formulation, and integrate climate within the planning and implementation stages. In this respect, ecosystem service (ES) based adaptation $(\mathrm{ESbA})$ is one of the commonly adopted approaches for coping with climate and environmental changes. ES are defined as 'the benefits to people obtained directly and indirectly from the ecosystem'. These services are categorized into four areas: provisioning services (food, raw material, fresh water etc.); regulating services (air quality and climate regulation, protection from disaster etc.); cultural services (educational, inspirational etc.); and supporting services like (nutrient cycling, soil formation etc. (MA 2005). ESbA is defined as the use of ES in supporting people in adapting to climate change (WertzKanounnikoff et al. 2011; Ash and Ikkala 2009; Vignola et al. 2009), largely through the maintaining and building resilience against climate change (Ash and Ikkala 2009 and UNEP 2009).

Previous studies have focused on the conceptual framework of main-streaming climate change in development (Huq and Reid 2004) and ecosystem based climate change adaptation (Wertz-Kanounnikoff et al. 2011; Ash and Ikkala 2009 and UNEP 2009). But few studies have focused on ESbA activities in development plans (Rao et al. 2012 and Andrade et al. 2011) and vulnerability analysis using the ES concept (Metzger et al. 2006). For example, Metzger et al. (2006) mainly limited their study to the vulnerability of ES caused by land use change, whereas other studies (e.g. Krishnamurthy et al. 2011a, b; Ahsan 2010) concentrated on climate change vulnerability analysis, but did not include ES. Rao et al. (2012) and Andrade et al. (2011) have provided guidelines for ESbA with some case studies. But none of these studies provides a conceptual model for ESbA that can be implemented in the real world. Therefore, in this study, we attempt to create a new conceptual model for 
ESbA and demonstrate its use in an empirical case study where ES and climate change adaptation are integrated within a development plan. Alongside the methodological development, the study examines the following questions:

1. What are the drivers and pressures of change in wetland ecosystem?

2. What are the ES in wetland ecosystems and how do they relate to the livelihoods of people?

3. What are the kinds of vulnerability in the study area?

4. What will be the future impact of climate change in terms of future rainfall and temperature change?

5. What are the plausible adaptation options for integrating ES and climate change responses in development plans?

\section{Materials and methods}

\subsection{Study area}

The south western coastal district Narail comprises an area of $990 \mathrm{sq} \mathrm{km}$ with a population of 730,568 . It receives $1,467 \mathrm{~mm}$ annual rainfall with a $37.1{ }^{\circ} \mathrm{C}$ maximum and $11.2{ }^{\circ} \mathrm{C}$ minimum temperature (Banglapedia 2011). The hydrological regime of the study area is governed by the Chitra river in the west and Nabaganga River to the north, east and south and by low-lying areas (wetlands) through the interconnected channels and water courses. Soils of this area are relatively fine-textured, heavy, with low permeability (ADB 2005).

Narail is a poor, agricultural district vulnerable to erosion and drought (ADB 2005; NAPA 2005). Nearly three-quarters (73\%) of the total population are engaged in agricultural activities and $\sim 50 \%$ of the population have incomes below the poverty line (Saadat and Islam 2011; ADB 2005). About $2 \%$ of the population is engaged in aquaculture (Banglapedia 2011) but most of the farmers are also involved in fishing all year round (Ahmed 2008). 30-50 \% of the population actually catches fish during the wet season. Hydro-meteorological changes due to climate and hydraulic engineering are making the community more vulnerable (Moni and Hossain 2010), with climate change dominating over all the other environmental problems in the last decade (Hossain et al. 2010). Narail is not strongly affected by the rising salinity linked to shrimp farming, which is very common in other coastal areas (Fig. 1).

\subsection{Conceptual framework}

Our starting point is the DPSIR (Driver-Pressure-State-Impact-Response) framework (Kristensen 2004), chosen for its wide capacity to develop management responses (Sekovski et al. 2012) from analyses of socioeconomic issues, environmental changes and policy responses (Bidone and Lacerda 2004). In addition, this framework allows the detailed analysis as an interdisciplinary tool to simplify the environmental complexities in the management process. It has been widely used in different contexts such as the European Union (EU) Water Framework Directive (Mysiak et al. 2005), fisheries management (Mangi et al. 2007), coastal zone management (Sekovski et al. 2012; Bidone and Lacerda 2004), wetland (Lin et al. 2007) and marine protected area management (Ojeda-Martínez et al. 2009).

For our purposes, the DPSIR framework has the potential to integrate ES and climate change by identifying the pressures, current States and future Impacts on ecosystems and their services due to climate and other drivers. Moreover, the 'State' part of the framework is 


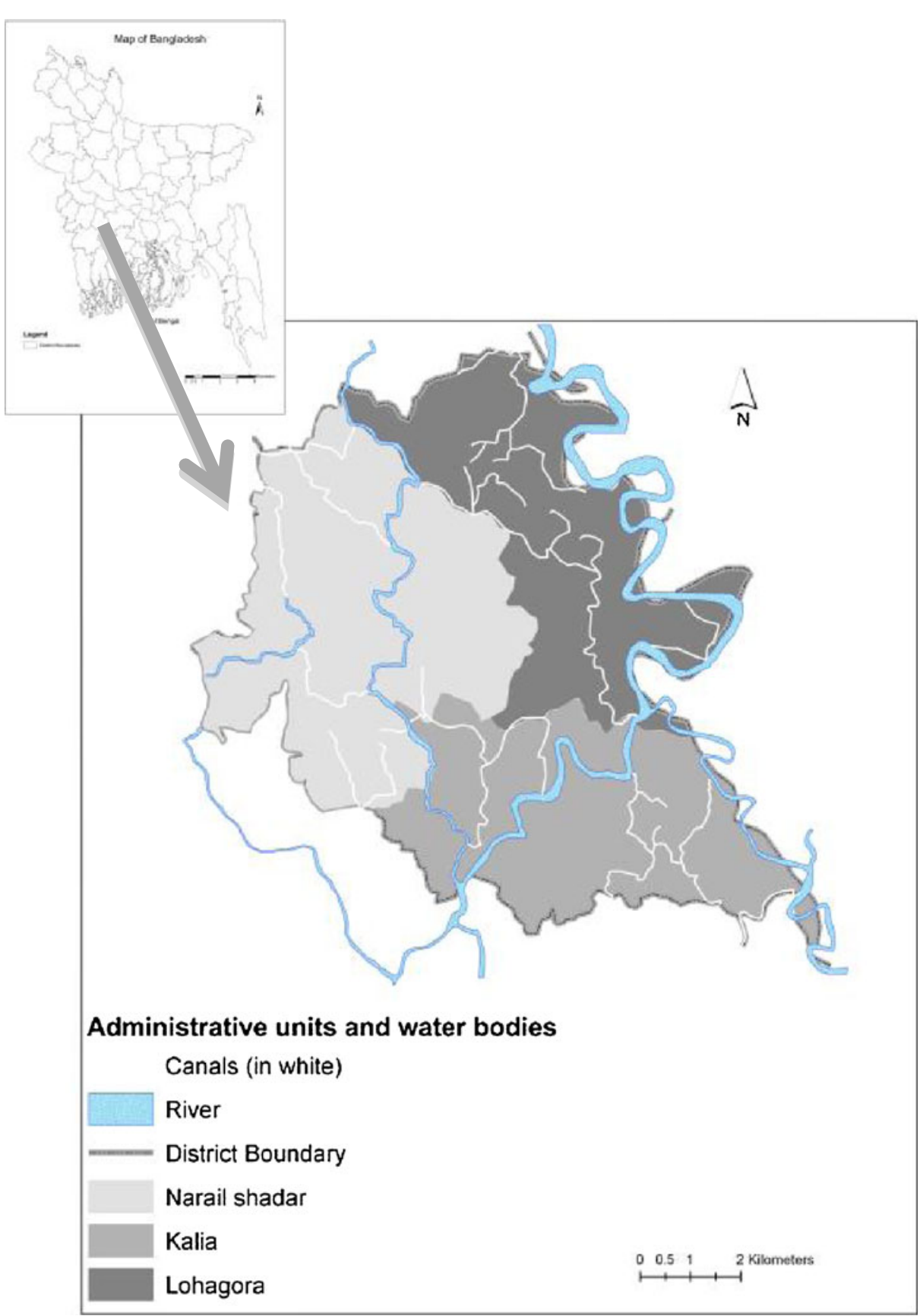

Fig. 1 South west coastal district Narail selected as study area in Bangladesh

useful for identifying ES and their vulnerability to climate. The 'Response' part emphasizes the need to determine mitigation and adaptation options. But we modify the framework (Fig. 2) to include links that allow for the integration of climate change responses and ES in future 


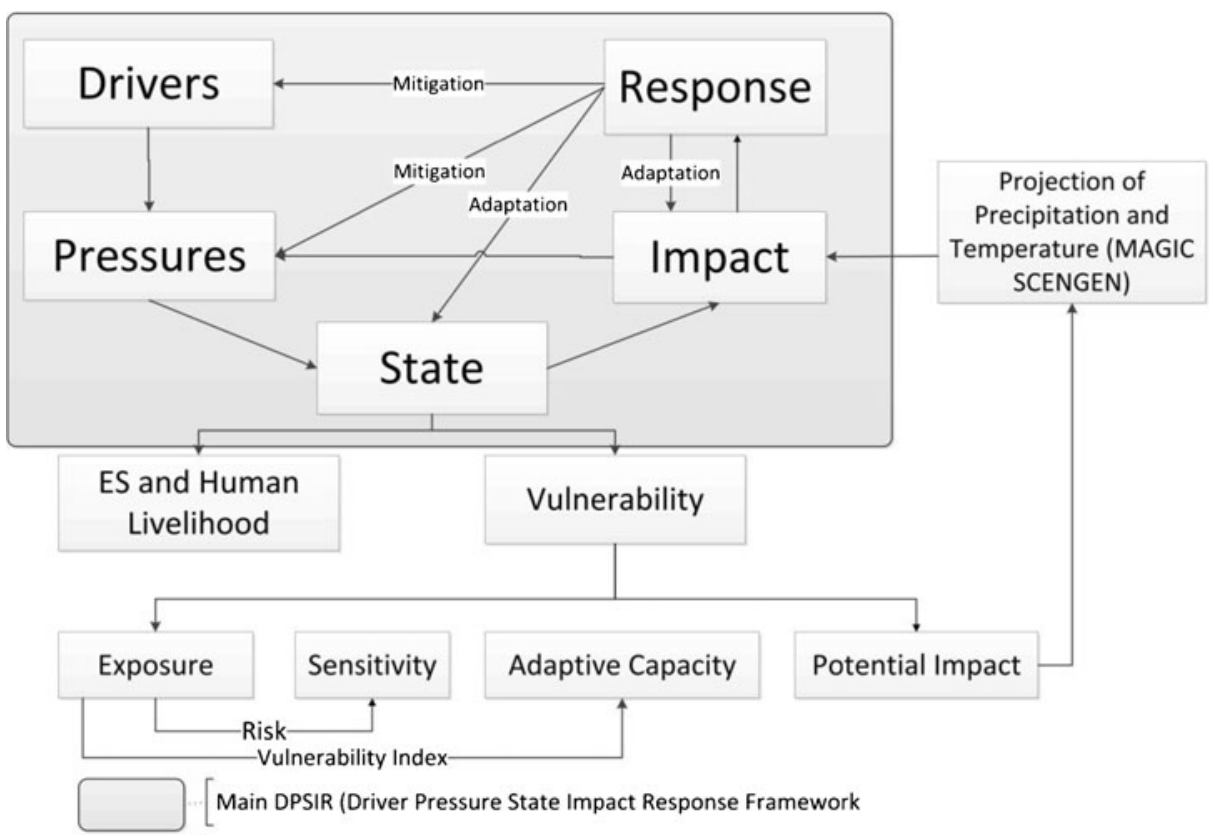

Fig. 2 Conceptual framework for integrating ecosystem services and climate change responses in Bangladesh development plans

development plans. Thus, the current State is determined by understanding the relationship between human livelihood and ES, and by assessing the vulnerability of the area. Future Impacts are assessed by projecting temperature and precipitation, which may impose extra Pressures on the environment. Finally, we propose adaptation Responses to climate and other changes.

\subsection{Methods}

\subsubsection{Identification of drivers and pressures}

Drivers and pressures were identified using stakeholder's perceptions through focus group discussion (FGD) with findings validated by analyzing secondary data, literature review and expert opinion. Monitored data records for past climate have been divided into 20 year segments (1948-1970, 1971-1990 and 1991-2007) in order to observe the temperature and rainfall trends. Bangladesh seasons have been classed as monsoon (June-July-August), post-monsoon (September-October-November), winter (December-January-February) and pre-monsoon (March-April-May) (Islam and Uyeda 2007).

\subsubsection{ES and livelihoods}

The relationships between ES and livelihoods are identified using the information from FGDs and secondary sources. There is a lack of data and literature for cultural, regulation and supporting services so we focus our analyses on the relationships between livelihoods and provisioning services, which are generally considered to be strong and intense (MA 2005). 


\subsubsection{Vulnerability analysis}

A geographic information systems GIS-based vulnerability assessment has been carried out by developing an index:

$$
\text { Vulnerability }=f((\text { Exposure }+ \text { Sensitivity })-\text { Adaptive Capacity })
$$

These three concepts of exposure, sensitivity and adaptive capacity have been adopted from Krishnamurthy et al. (2011a), Damm (2010), Luers et al. (2003) and IPCC (2001). In this study, we use four domains of information: exposure (hazard), sensitivity (ecosystem services), adaptive capacity (infrastructure plus socio-economic structure) and a number of indicator criteria for climate change, ecosystem services, regional problems, livelihood, economy and society (Table 1). For each of three sub-district (upazila) areas, relative indicators were scaled according to $\mathrm{X}_{\mathrm{i}}-\mathrm{X}_{\min } / \mathrm{X}_{\max }-\mathrm{X}_{\min }$ (adopted from the International Poverty Index, Lawrence et al. 2002) where $X_{i}$ is the stated value for that upazila, and $X_{\min }$ and $\mathrm{X}_{\max }$ are the lowest and maximum values across the three upazila areas. The calculated indicator value indicates the relative position of the region and lies between 0 and 1 . Values for the four domains and hence the vulnerability index were calculated by summing the indicator values for all the datasets within a domain (Table 1). Finally, the total aggregated value was put through a query process to calculate the vulnerability of the area.

Most of the data (Table 1) for the vulnerability indicators was collected from secondary sources. But due to a lack of local data for climate, the spatial variability of hazards data (Table 1) was estimated using a problem matrix during the FGDs (see below). The matrix is based upon identification of the frequency and intensity of known hazards, with ranking on a scale of 1 to 5, and aggregated through the vulnerability index.

\subsubsection{Future impacts of climate change}

Impacts of climate change were assessed in two steps: first, climate change projections were produced from the MAGICC (Model for the Assessment of Greenhouse-gas Induced Climate Change)-SENGEN (SCEnario GENerator) model version 2 5.3, which is consistent with the IPCC (2007b). The best 4 GCM models identified by Roy et al. (2009) for each of the four seasons in south-west Bangladesh were used to calculate mean seasonal temperature and rainfall for 2030, 2050 and 2100. Using the global data set from the MAGICC/SCENGEN software, data were extracted for the geographic area enclosed by latitudes 22.50-25.00 and longitudes 87.50-90.00 (cf. center of study area $23^{\circ} 7^{\prime} 48^{\prime \prime} \mathrm{N}, 89^{\circ} 30^{\prime} 0^{\prime \prime}$ E). Projections were based on an A1- BAIM scenario. Second, the possible impacts of the projected climate changes were determined from expert judgment and literature sources (Table 2)

\subsubsection{Focus group discussion}

Plausible adaptation strategies that might include ES were based on stakeholder views and perceptions recorded during FGDs. In total, eight FGDs were conducted in the following sites of three upazila: Lohagora upazila (Permollik Pur and Noagram), Kalia upazila (Molladanga Bongram, Joynagar and Krishna Pur) and Narail Sadar upazila (Singa and Poloidanga Vodrobila). On average, there were 30 participants in each FGD, the majority fishermen and farmers of 40 years age or older who had lived in the area since childhood. These were selected in order to maximize an understanding of changes in the area over several decades, but high levels of illiteracy precluded formal questionnaire approaches. 
Table 1 Indicators for Bangladesh vulnerability index 2011

\begin{tabular}{|c|c|c|c|}
\hline \multicolumn{2}{|l|}{ Component } & \multirow{2}{*}{$\begin{array}{l}\text { Input } \\
\text { Indicator }\end{array}$} & \multirow[t]{2}{*}{ Data source } \\
\hline & Profile & & \\
\hline \multirow[t]{4}{*}{ Exposure } & Hazard & $\begin{array}{l}\text { Area of flooding }\left(\mathrm{km}^{2}\right) \text {, Number of affected } \\
\text { families Number of affected people, Crop } \\
\text { damage due to flood (Acre), Number of } \\
\text { flood affected houses }\end{array}$ & DC Office \\
\hline & & Damage due to river erosion (Number of families) & UP Office \\
\hline & & $\begin{array}{l}\text { Temperature, Precipitation, Waterlogging, } \\
\text { Flood, Erosion, Cyclone, Lack of irrigation, } \\
\text { Drinking water availability (Ground water depth), } \\
\text { Arsenic levels }\end{array}$ & FGD \\
\hline & & Salinity Level (River) (Summer Season) & SRDI \\
\hline \multirow[t]{5}{*}{ Sensitivity } & Ecosystem services & Agricultural Area, Forest Area (ha) & DAE \\
\hline & & $\begin{array}{l}\text { Wetland Area (ha), Fish production from wetlands } \\
\text { metric tonnes }(\mathrm{t}) / \mathrm{yr}\end{array}$ & DoF \\
\hline & & $\begin{array}{l}\text { Pond area (ha), Fish production from ponds (t/yr), } \\
\text { Shrimp farm area (ha), Shrimp production }(\mathrm{t} / \mathrm{yr}) \text {, } \\
\text { Number of fisherman, Riverine area (ha), Fish } \\
\text { production from river }(\mathrm{t} / \mathrm{yr})\end{array}$ & DoF \\
\hline & & Number of farmers & DAE \\
\hline & & Area of canal $\left(\mathrm{km}^{2}\right)$ & BWDB \\
\hline \multirow[t]{5}{*}{ Adaptive capacity } & Infrastructure & Roads (Solid, Kucha and Others) & LGED \\
\hline & & Embankment and sluice gates & BWDB \\
\hline & & Number of health and education center & DC Office \\
\hline & & Dwelling structure of household & BBS \\
\hline & $\begin{array}{l}\text { Socio-economic } \\
\text { structure }\end{array}$ & $\begin{array}{l}\text { Population density, Educational status, Population } \\
\text { growth (1991-2001) \%, Urban growth (1991-2001) } \\
\text { population, Population below poverty line, Children } \\
\text { (\%),Schooling (children) (\%), Women (\%), Sanitary } \\
\text { Coverage (\%), Electricity coverage }(\%)\end{array}$ & BBS \\
\hline
\end{tabular}

BBS Bureau of Statistics, BWDB Bangladesh Water Development Board, DoF Department of Fisheries, DC Office District Commissioner Office, DAE Department of Agricultural Extension, FGD Focused Group Discussion, LGED Local Government Engineering Department, SRDI Soil Resource Development Institute, UNO Upazila Parishad Office

Table 2 Best 4 GCMs for each of the 4 seasons in South-West Bangladesh for projecting temperature and precipitation

\begin{tabular}{llllll}
\hline GCM rank & Winter (DJF) & Pre-monsoon (MAM) & Monsoon (JJA) & Post-monsoon (SON) & Annual \\
\hline 1 & ECHO-G & ECHO-G & INMCM-3.0 & UKHADGEM & UKHAD-CM3 \\
2 & GISS-ER & CCCMA-3.1 & UKHAD-CM3 & UKHAD-CM3 & INMCM-3.0 \\
3 & GISS-EH & MRI-232A & GFDLCM2.0 & CNRMCM3 & CCSM-3.0 \\
4 & CSIRO-3.0 & INMCM-3.0 & CSIRO-3.0 & GFDLCM2.1 & CCCMA-3.1
\end{tabular}

Roy et al. (2009) 
First, we asked the participants about the existing hazards in the area and the possible impacts on livelihood and ES. We also asked the participants about how to reduce the vulnerabilities, including the use of ES assets. Then we asked the participants about the drivers of the vulnerabilities that they had stated. Then we framed the discussions as per our conceptual framework and validated the overall group messages using a flip chart diagram. In open discussion we learned about the changes in the drivers and the pressures.

The same framework was used to collect data from professionals in non government organizations (NGOs), the Water Development Board, Agricultural Department, Fisheries Department, and academics who have worked in the area. The outcomes of the FGDs, especially water-related, were validated through consultation with experts. Finally, we drew upon national strategies, including the Bangladesh National Adaptation Program of Action (NAPA 2005) and the Bangladesh Climate Change Strategy and Action Plan (BCCSAP 2008 ) to deduce and recommend final adaptation options. Some of the options, such as improving literacy, are regular development priorities but were retained as recommendations if there was evidence that they were explicitly linked to desirable adaptation options.

\section{Results}

\subsection{Drivers of change}

Stakeholders identified the hydrological effects of the Farakka Barrage, climate change and population growth as the major drivers affecting the local ecosystems and services. Table 3 shows that the population increased over the period 1951-2001. Though population growth rate has declined $(0.53 \% / y r)$ since 1991 , population has doubled within a 40 year time period.

\subsection{Pressures on ecosystem}

Flood and river bank erosion Narail experienced a severe flood event in 1987 that affected around 300,000 people and damaged 32,000 acres of crops. In 1988, flooding affected $1,000 \mathrm{~km}^{2}$ and 385,000 inhabitants. Lohagora upazila was severely affected compared to other upazila. Around 10,000 people were affected by the floods of 2007 . The 2004 and 2008 floods inundated $\sim 19 \%$ and $\sim 40 \%$ area of district respectively. In 2011, around 2,000 households were affected by river bank erosion but there is no previous statistical data.

\subsubsection{Low water flow}

Water discharge values of the Gorai-Modhumoti river show a declining trend in the period 2001-2010. Water discharge declines in both the monsoon $\left(-84 \mathrm{~m}^{3} / \mathrm{s} / \mathrm{yr}\right)$ and post monsoon

Table 3 Population growth and density in Narail District, 1951-2001

\begin{tabular}{lllllll}
\hline Characteristics & 1951 & 1961 & 1974 & 1981 & 1991 & 2001 \\
\hline Population & 310,000 & 379,000 & 505,000 & 588,000 & 655,000 & 698,000 \\
Population Density (Narail) & 319 & 383 & 510 & 595 & 662 & 705 \\
Population Density (Urban) & - & - & 518 & 573 & 640 & 673 \\
Population Density (Rural) & 319 & 383 & 502 & 886 & 945 & 1055 \\
\hline
\end{tabular}

Bangladesh Bureau of Statistics (BBS) 

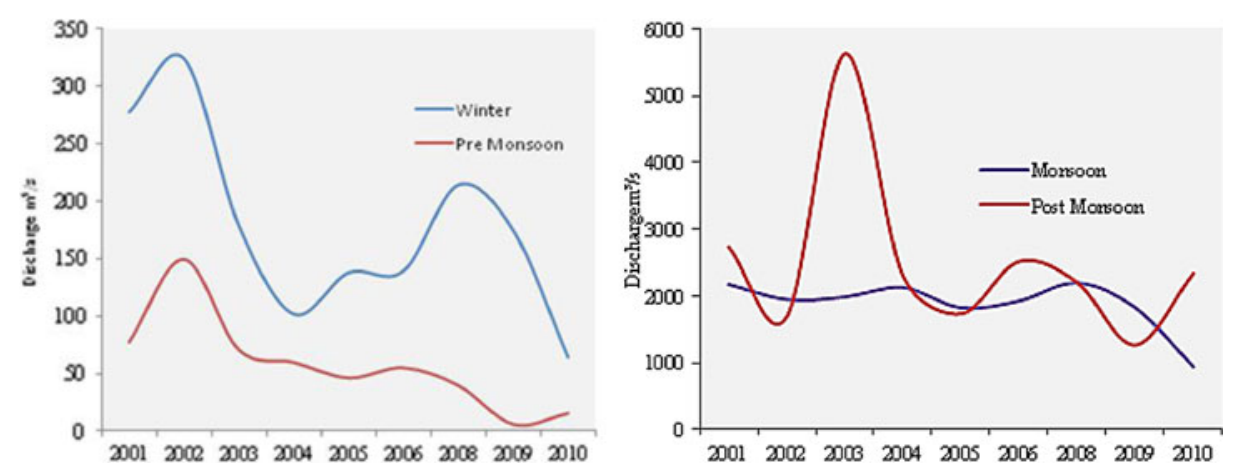

Fig. 3 Dry (left) and wet (right) seasonal water discharges in Gorai Madhumoti river over the period 20012010. Data Source Bangladesh Water Development Board

$\left(-158 \mathrm{~m}^{3} / \mathrm{s} / \mathrm{yr}\right)$ season. Though the post monsoon rate is declining, this is because of the extreme value $\left(<5000 \mathrm{~m}^{3} / \mathrm{s}\right)$ in 2003 , whereas the average water discharge is $\sim 2000 \mathrm{~m}^{3} / \mathrm{s}$ from 2001 to 2010 . The winter season trend also shows a declining trend $\left(-19.89 \mathrm{~m}^{3} / \mathrm{s}\right)$ for the same time period. Community people and experts have reported that these declines are linked to the water diversion project in the Indian section of the Ganges, the upstream part of this river network (Fig. 3).

\subsubsection{Temperature and precipitation}

Overall temperature has increased $0.39{ }^{\circ} \mathrm{C}$ to $0.79{ }^{\circ} \mathrm{C}$ in the time period $1970-2007$. Monsoon temperature has increased by $1{ }^{\circ} \mathrm{C}$ within the past 60 years. Temperatures declined in post-monsoon and pre-monsoon periods by $-0.21^{\circ} \mathrm{C}$ and $-0.11^{\circ} \mathrm{C}$ respectively before 1990 , followed by increasing trends of $0.79{ }^{\circ} \mathrm{C}$ and $0.39{ }^{\circ} \mathrm{C}$ respectively after $1990 \mathrm{~s}$. Only the winter temperature shows a declining trend after the 1990s (Tables 4 and 5). Since the $1990 \mathrm{~s}$, mean daily rainfall in the wet seasons has increased (monsoon: $0.83 \mathrm{~mm} /$ day and post-monsoon: $1.94 \mathrm{~mm} /$ day/yr) while mean daily rainfalls in the dry seasons have declined (pre-monsoon: $-0.24 \mathrm{~mm} / \mathrm{day} / \mathrm{yr}$ and winter: $-0.30 \mathrm{~mm} / \mathrm{day} / \mathrm{yr}$ ).

\subsection{State of ecosystem and livelihood}

\subsubsection{ES and Livelihood}

We identified three types provisioning services covering around 28 types of different crops, and freshwater fish, including cultivated area and agricultural production (Table 6). The wetland ecosystem supports the production of $\sim 235,000 \mathrm{t}$ rice, 7,000 $\mathrm{t}$ wheat, and $63,000 \mathrm{t}$

Table 4 Decadal temperature change $\left({ }^{\circ} \mathrm{C}\right)$ over the period 1948-2007 in Narail, Bangladesh

\begin{tabular}{|l|l|l|l|l|}
\hline Year & Monsoon & Post Monsoon & Winter & Pre Monsoon \\
\hline $1948-1970$ & 28.99 & 26.15 & 19.05 & 27.89 \\
\hline $1971-1990$ & 29.25 & 25.94 & 19.69 & 27.78 \\
& +0.27 & -0.21 & +0.63 & -0.11 \\
\hline $1991-2007$ & 29.98 & 26.73 & 19.56 & 28.17 \\
& +0.72 & +0.79 & -0.12 & +0.39 \\
\hline
\end{tabular}

Bangladesh Meteorological Department 
Table 5 Decadal rainfall change (mm/day/yr) over the period 1948-2007 in Narail, Bangladesh

\begin{tabular}{|l|l|l|l|l|}
\hline Year & Monsoon & Post Monsoon & Winter & Pre Monsoon \\
\hline $1948-1970$ & 19.47 & 10.07 & 5.11 & 0.57 \\
\hline $1971-1990$ & 19.34 & 9.16 & 6.28 & 1.18 \\
& -0.13 & -0.904 & +1.17 & +0.60 \\
\hline $1991-2007$ & 20.17 & 11.11 & 5.98 & 0.94 \\
& +0.83 & +1.94 & -0.30 & -0.24 \\
\hline
\end{tabular}

Bangladesh Meteorological Department

vegetables per year. It also produces $\sim 4,000 \mathrm{t}$ fish and 1,000 $\mathrm{t}$ shrimp together with 2,000 $\mathrm{t}$ potatoes and $\sim 4,500 \mathrm{t}$ different types of spices. These provisioning services are the sources of income for around 134,000 farmers and 16,000 fishermen and also contribute to the food security of 700,000 inhabitants. Surplus goods from these provisioning services are exported to the national and international markets after local demand is met.

Wetland in this area has the potential to accumulate around $126,700 \mathrm{CO}_{2} \mathrm{e}^{1} \mathrm{~km}^{-2} \mathrm{yr}^{-1}$ to 253,500 $\mathrm{CO}_{2} \mathrm{e} \mathrm{km}^{-2} \mathrm{yr}^{-1}$ (calculated as per Crooks et al. 2011). The study area covers around 69,000 ha of wetlands area which acts as a water reservoir during the dry season. Hence, the wetlands serve as the source for irrigation water during the dry season and fish production. Moreover, Hizal (Barringtonica acutangula) and Koroch (Pongamia pinnata) plants grow in wetland areas, are the feeding and breeding zone for fish. Water reservoirs including rivers, wetlands and canals protect life and property by acting as water storage during flood time.

Income generated from the provisioning services enables people to celebrate cultural and religious programs. Farmers and fishermen also have their own cultural program such as Nouka Baich (boat race) and Nobanno (festivals after rice harvesting). The low production results insufficient income to meet their daily need, whereas they also could not celebrate religious and cultural festivals. Moreover, this wetland serves as the source of aesthetic, religious experience (for instance, Hindu people do worship in rivers and wetlands) and also a source of educational value. From this, it could be concluded that ecosystem services and human livelihood are strongly correlated and without the ecosystem, livelihood in this area could not be sustained.

\subsection{Vulnerability index}

Maps of the aggregated vulnerability index show that Lohagora upazila has the highest levels of risk exposure (Fig. 4a), twice as high as Kalia and Narail Sadar. Although it has a high adaptive capacity (Fig. 4b), Lohagora has high sensitivity (Fig. 4c), making it the most vulnerable area (Fig. 4d) to hazards. Narail Sadar is the second most vulnerable upazila which is mostly threatened because of the low adaptive capacity and high sensitivity. Kalia upazila has low vulnerability due to the medium level of adaptive capacity together with low levels of sensitivity and exposure to hazard.

\subsection{Future impacts of climate change}

The GCM outputs provided by MAGICC/SCENGEN for the study area indicate that there will be a further increase in seasonal temperature over the period 2030-2100 (Fig. 5). By 2100 , the length of the summer will be extended and reach an average temperature of $30^{\circ} \mathrm{C}$

$1 \mathrm{gC} \equiv 3.67 \mathrm{gCO} 2 \mathrm{e}$ 
Table 6 Quantification of provisioning services in the study area

\begin{tabular}{|c|c|c|c|c|}
\hline Services & Functions & & & \\
\hline \multirow[t]{25}{*}{ Food } & Food item & & $\begin{array}{l}\text { Cultivated area } \\
\text { (Hectare) }\end{array}$ & $\begin{array}{l}\text { Production } \mathrm{yr}-1 \\
\text { (M.T) }\end{array}$ \\
\hline & Rice & Oryza sativa & & \\
\hline & Ropa Amon & & 33,000 & 71,000 \\
\hline & Boro & & 36,000 & 141,000 \\
\hline & Aus & & 5,000 & 7,000 \\
\hline & Bona Amon & & 15,000 & 15,000 \\
\hline & Wheat & Triticum aestivum & 3,000 & 7,000 \\
\hline & Corn & Zea mays & 3 & 9 \\
\hline & Grass Pea & Lathyrus sativus & 11,000 & 9,000 \\
\hline & Lentil & Lens culinaris & 3,000 & 2,000 \\
\hline & Pea & Pisum sativum & 52 & 350 \\
\hline & Chick Pea & Cicer arietinu & 500 & 37 \\
\hline & Mung Beans & Vigna radiata & 190 & 182 \\
\hline & Black Gram & Vigna mungo & 52 & 38 \\
\hline & Mustard & Brassica nigra & 4,500 & 2,000 \\
\hline & Linseed & Linum usitatissimum & 43 & 305 \\
\hline & Peanuts & Arachis hypegaea & 419 & 741 \\
\hline & Chili & Capsicum annum & 653 & 1,000 \\
\hline & Potato & Solanum tuberosum & 135 & 2,000 \\
\hline & Sweet Potato & Ipomoea batatas & 84 & 1,400 \\
\hline & Vegetable & & 4,412 & 63,000 \\
\hline & Til & Sesamum indicum & 1,740 & 1,000 \\
\hline & Sugar Cane & Saccharum officinarum L. & 580 & 26,000 \\
\hline & Fish & & 9,900 & 4,000 \\
\hline & Shrimp & & 2,000 & 1,000 \\
\hline \multirow[t]{7}{*}{ Raw material } & Spices & & & \\
\hline & Onion & Allium cepa & 499 & 3,700 \\
\hline & Garlic & Allium sativum & 98 & 533 \\
\hline & Ginger & Zingiber Officinale & 12 & 72 \\
\hline & Turmeric & Curcuma longa & 80 & 240 \\
\hline & Coriander & Coriandrum sativum & 454 & 350 \\
\hline & Jute & Corchorus capsularis & & 109,000 bell \\
\hline \multirow[t]{4}{*}{ Fresh water } & Type of source & & Area hectare & \\
\hline & Wetlands & & 6,000 & \\
\hline & Ponds & & 1,000 & \\
\hline & Rivers & & 1,900 & \\
\hline
\end{tabular}

BBS (2011)

for all seasons. Although there will be an increase in temperature, there will be seasonal variations and the seasons will still be distinguishable in 2030 and 2050 (Fig. 5).

Winter temperature will increase from 2 to $5^{\circ} \mathrm{C}$ between the years 2030 and 2100 (Fig. 5). There will be $\sim 1^{\circ} \mathrm{C}, 2^{\circ} \mathrm{C}$ and $4{ }^{\circ} \mathrm{C}$ temperature rises in the pre-monsoon season in years 2030 , 2050 and 2100 respectively. Although the changes in monsoon and post-monsoon temperatures 


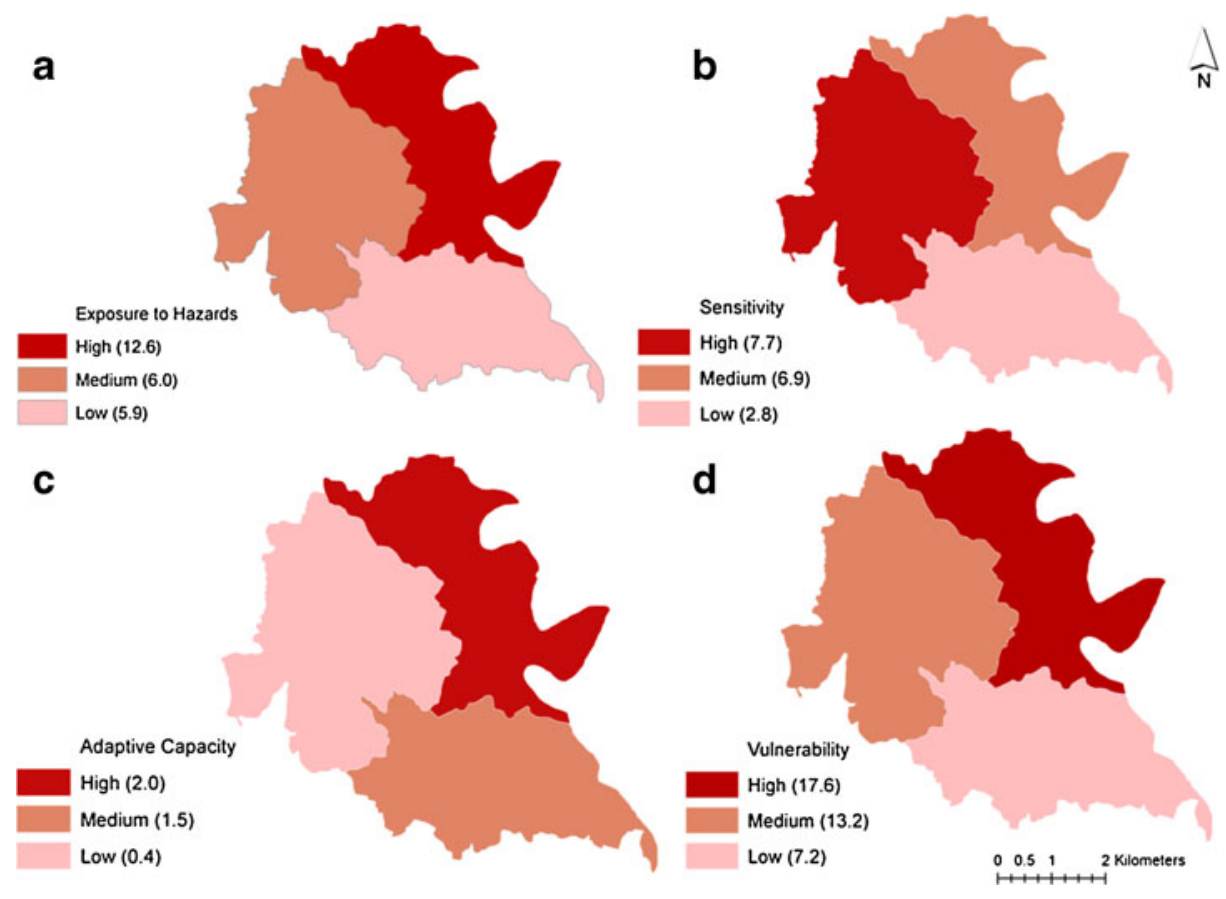

Fig. 4 Comparative vulnerability analysis (d) in the three administrative areas of Narail district in Bangladesh considering exposure to hazards (a), sensitivity (b) and adaptive capacity (c)

$\left(1-3{ }^{\circ} \mathrm{C}\right)$ are not high compared to the winter and pre-monsoon seasons, these increases are still substantial because the mean temperatures will be higher (Fig. 6). An increase of $\sim 3{ }^{\circ} \mathrm{C}$ is predicted both in monsoon and post-monsoon seasons for 2100 .

During the community consultation, it was reported that, recently, rainfall is occurring more intensively within a short duration. Whereas the monsoon period usually has the peak rainfall season, observations suggest that the post-monsoon season is now showing higher rainfall

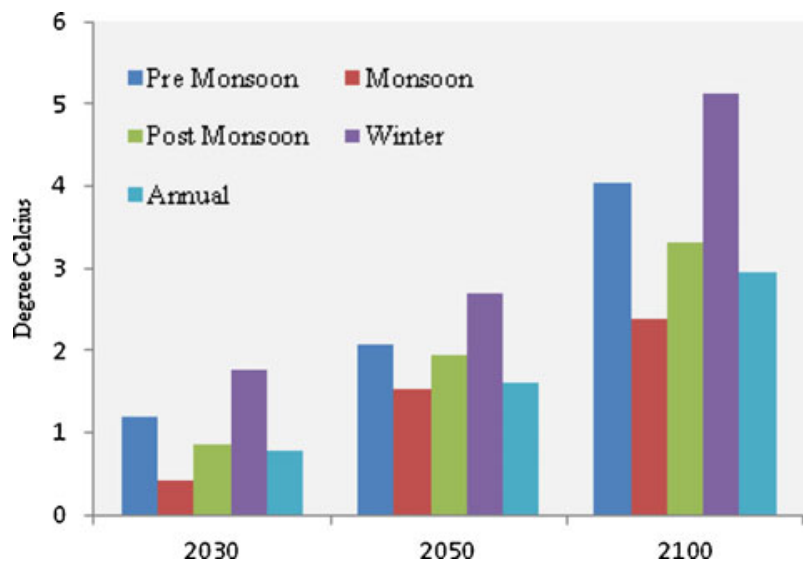

Fig. 5 Forecasted changes in Bangladesh seasonal temperature over the period 2030-2100 by using GCM models 


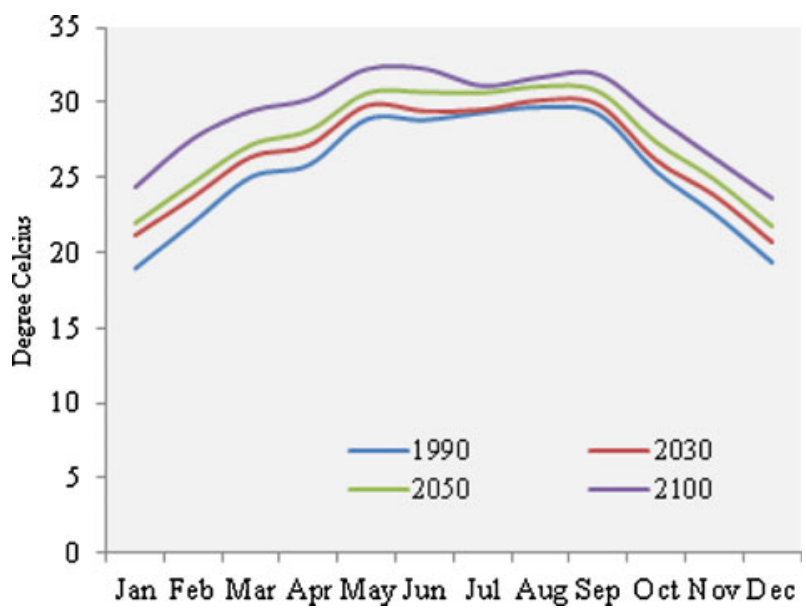

Fig. 6 Forecasted changes in Bangladesh monthly temperature over the period 2030-2100 by using GCM models

totals. GCM outputs (Fig. 7) suggest that these recent changes will continue in the future. Rainfall increases will not occur in all seasons but will occur intensively in the mid-monsoon and post-monsoon seasons, with the post-monsoon season seeing the largest increases.

Forecasted changes in rainfall show a reduction in winter by around $60 \%, 10 \%$ and $90 \%$ in the years 2030, 2050 and 2100 respectively (Fig. 7). In contrast, changes in the monsoon and post-monsoon rainfall will show a sharp increase. There will be a $14 \%, 8 \%$ and $23 \%$ increase in monsoon rainfall by the years 2030, 2050 and 2100 respectively. These increases in rainfall will also continue into the post-monsoon season (by $6 \%, 12 \%$ and $9 \%$ by the year 2030,2050 and 2100 respectively). The plausible impacts of these temperature and rainfall increases in the Narail district are summarized (Table 7) as changes in DPSIR Pressure and States.

In summary, the production of local grains (rice and wheat) is expected to decline with a projected $1-5{ }^{\circ} \mathrm{C}$ increase in temperature, which will also affect the growth of vegetables like potato. These plausible changes in provisioning services will pose a threat to the food security of the area. Where the seasonality of rainfall changes, the late monsoon may see a heightened risk of flood and water logging, while there is likely to a worsening of water availability in the dry

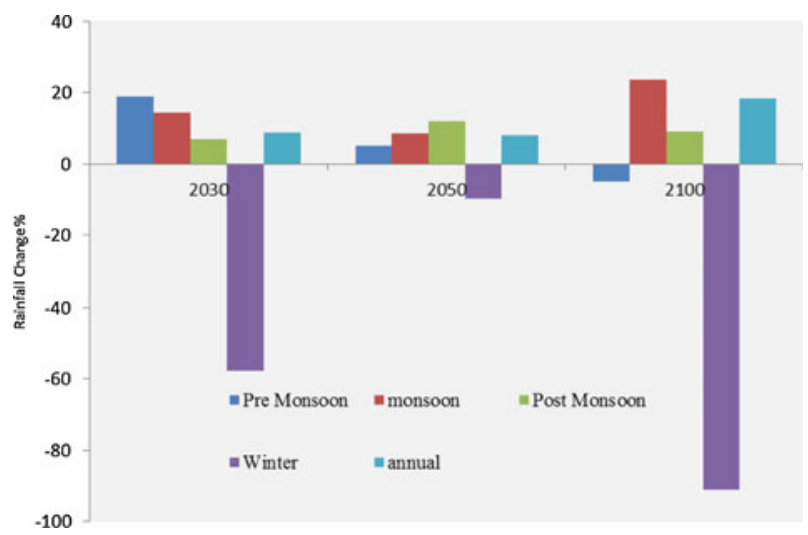

Fig. 7 Forecasted changes (\%) in Bangladesh seasonal rainfall over the period 2030-2100 by using GCM models 
Table 7 Possible impacts of temperature and rainfall change on pressures and states in Narail district

\begin{tabular}{|c|c|c|}
\hline Climatic parameters & Change in pressure & Changes in state \\
\hline $\begin{array}{l}\text { Increase of } 0-5{ }^{\circ} \mathrm{C} \\
\text { temperature }\end{array}$ & $\begin{array}{l}\text { Flood magnitude and frequency } \\
\text { are likely to increase (IPCC } \\
2007 \mathrm{~b} \text { ) }\end{array}$ & $\begin{array}{l}\text { Increase in flood area } 25-50 \% \text { for } 2-5{ }^{\circ} \mathrm{C} \\
\text { (IPCC 2007b) }\end{array}$ \\
\hline \multirow{16}{*}{$\begin{array}{l}\text { Change in rainfall } \\
\text { pattern with increase } \\
\text { of rainfallup to } \\
20 \% \text { in monsoon, } \\
\text { post-monsoon and } \\
\text { pre-monsoon }\end{array}$} & $\begin{array}{l}\text { Inhibition of primary production } \\
\text { (IPCC 2001) }\end{array}$ & $\begin{array}{l}\text { Enhanced evaporation demand may cause an } \\
\text { increase in irrigation demand (IPCC 2007b) }\end{array}$ \\
\hline & $\begin{array}{l}\text { Changes in surface water quality } \\
\text { and ground water characteristics } \\
\text { (IPCC 2001) }\end{array}$ & $\begin{array}{l}\text { Ecosystems and species are very likely to show } \\
\text { a wide range of vulnerabilities to climate } \\
\text { change }\end{array}$ \\
\hline & $\begin{array}{l}\text { Increase of coastal erosion (IPCC } \\
\text { 2001) }\end{array}$ & $\begin{array}{l}\text { Low water flows are likely to decrease in many } \\
\text { regions }\end{array}$ \\
\hline & $\begin{array}{l}\text { Seawater intrusion into fresh } \\
\text { groundwater (IPCC 2001) }\end{array}$ & \multirow{3}{*}{$\begin{array}{l}\text { Soil properties and processes including organic } \\
\text { matter decomposition, leaching, and soil } \\
\text { water regimes will be influenced by the } \\
\text { temperature increase (IPCC } 2007 \mathrm{~b} \text { ). For } \\
\text { example, }>11 \% \text { loss of soil organic matter } \\
\text { with a } 3^{\circ} \mathrm{C} \text { rises in temperature (Khan et al. } \\
\text { 2011). }\end{array}$} \\
\hline & $\begin{array}{l}\text { Elevated ground and water } \\
\text { temperatures (IPCC 2001) }\end{array}$ & \\
\hline & Increase of drought (IPCC 2007b) & \\
\hline & & $-35 \%-30 \%$ Aus yield decrease for $2-4{ }^{\circ} \mathrm{C}$ \\
\hline & & $-8 \%-4 \% A M O N$ yield reduction for $2-4{ }^{\circ} \mathrm{C}$ \\
\hline & & $-4 \%$ Boro yield reduction for $2-4{ }^{\circ} \mathrm{C}$ \\
\hline & & $-63 \%-22 \%$ wheat reduction for $2-4{ }^{\circ} \mathrm{C}$ \\
\hline & & (Karim et al. 1996) \\
\hline & & $\begin{array}{l}\text { Mean temperature }>20{ }^{\circ} \mathrm{C} \text { will depress tuber } \\
\text { initiation and bulking of potatoes. }\end{array}$ \\
\hline & & $\begin{array}{l}\text { Pollen loses its viability at temperatures }>36^{\circ} \mathrm{C} \\
\text { (Khan et al. 2011). }\end{array}$ \\
\hline & & $\begin{array}{l}\text { Water scarcity in wetlands and canals will lead } \\
\text { to disruption of wetlands (IPCC 2007b) }\end{array}$ \\
\hline & & Increase of salinity (IPCC 2007b) \\
\hline & & $\begin{array}{l}\text { More socio-economic damage due to flood, } \\
\text { erosion and extreme weather events. In- } \\
\text { creased flood inundation in post-monsoon } \\
\text { due to excessive rainfall (IPCC } 2007 \mathrm{~b} \text { ). }\end{array}$ \\
\hline
\end{tabular}

season. However, increases in temperature and salinity will increase the suitability of shrimp farming which could be attractive as an alternative livelihood, despite the evidence that this land use has already had serious negative consequences in the coastal zone.

\section{Responses}

Potential adaptive management responses to climate change through an integration of ecosystem services with development plans are shown in Table 8.

\subsection{Mitigation and adaptation}

For mitigating the drivers, population growth reduction is the only one that can be addressed directly by the Bangladesh government, because other drivers (climate change and water resource management) are dependent on international and regional scale (south Asian) policies. Thus, most 
Table 8 Response framework for integrating ecosystem services and climate change in development plans. Hazards and vulnerability are summarized from the FGD and vulnerability analysis findings, where plausible impacts are summarized from the future impacts of climate change (Table 7). Finally, responses for adaptation and mitigation strategies are proposed from stakeholder consultation and the national policy review

\begin{tabular}{|c|c|c|c|}
\hline $\begin{array}{l}\text { Vulnerability } \\
\text { Classification } \\
\text { (hazard) }\end{array}$ & Vulnerability-Situation & $\begin{array}{l}\text { Plausible impacts on } \\
\text { Ecosystem Services }\end{array}$ & Responses \\
\hline $\begin{array}{l}\text { Temperature: } \\
\text { - Rise of } \\
\text { Tempera- } \\
\text { ture } \\
\text { - Extension } \\
\text { of } \\
\text { Summer } \\
\text { - Drought } \\
\text { Precipitation } \\
\text { - Shifting of } \\
\text { rainfall } \\
\text { pattern. } \\
\text { - Sudden and } \\
\text { intense } \\
\text { rainfall } \\
\text { - Abrupt } \\
\text { changes in } \\
\text { rainfall } \\
\text { Flood } \\
\text { River } \\
\text { Erosion } \\
\text { Water } \\
\text { Logging } \\
\text { Salinity }\end{array}$ & $\begin{array}{l}\text { Loss of food grains production } \\
\text { Increase in production cost. } \\
\text { Fisheries resource reduction. } \\
\text { Surface water salinity in } \\
\text { dry season. } \\
\text { Inundation of agricultural land } \\
\text { due to water logging. } \\
\text { Less rainfall in pre-monsoon } \\
\text { and monsoon season is } \\
\text { increasing dependency on } \\
\text { irrigation water } \\
\text { Sudden and heavy unseasonal } \\
\text { rainfall is increasing river } \\
\text { erosion, water logging and } \\
\text { ultimately damaging crops, } \\
\text { houses etc. } \\
\text { Increase of temperature and } \\
\text { extension of summer are } \\
\text { decreasing water } \\
\text { availability in river, } \\
\text { wetland, and ponds. } \\
\text { Salinity rise in dry season due } \\
\text { to declining rainfall trends } \\
\text { and temperature increase }\end{array}$ & $\begin{array}{l}\text { Provisioning services: } \\
\sim 30 \% \text { local rice (Aus) and } \\
\text { verities and } \sim 50 \% \text { wheat } \\
\text { produce reduction for } 2- \\
4{ }^{\circ} \mathrm{C} \text {. } \\
\text { Reduction of fresh water } \\
\text { Regulatory Services: } \\
1-5{ }^{\circ} \mathrm{C} \text { temperature increase } \\
\text { from } 2010 \text { to } 2100 . \\
\text { Intense summer and the } \\
\text { average temperature of } \\
30{ }^{\circ} \mathrm{C} \text { over the years in } \\
2100 . \\
20 \% \text { rainfall increase in } \\
\text { monsoon and post } \\
\text { monsoon season. } \\
\text { Rainfall shifting from monsoon } \\
\text { to post } \\
\text { monsoon season. } \\
\text { Increase of flood } \\
\text { (25-50 \%) } \\
\text { Low water flow } \\
\text { Increase of salinity } \\
\text { and river erosion. } \\
\text { Supporting services: } \\
\text { Inhibition of primary } \\
\text { production } \\
11 \% \text { decrease of soil organic } \\
\text { matter for } 3{ }^{\circ} \mathrm{C} \\
\text { Cultural Services: } \\
\text { For reduction in local crops } \\
\text { especially rice varieties, some } \\
\text { of the cultural services } \\
\text { (Nouka Baich, Nobanno) } \\
\text { will be extinct. } \\
\text { and }\end{array}$ & 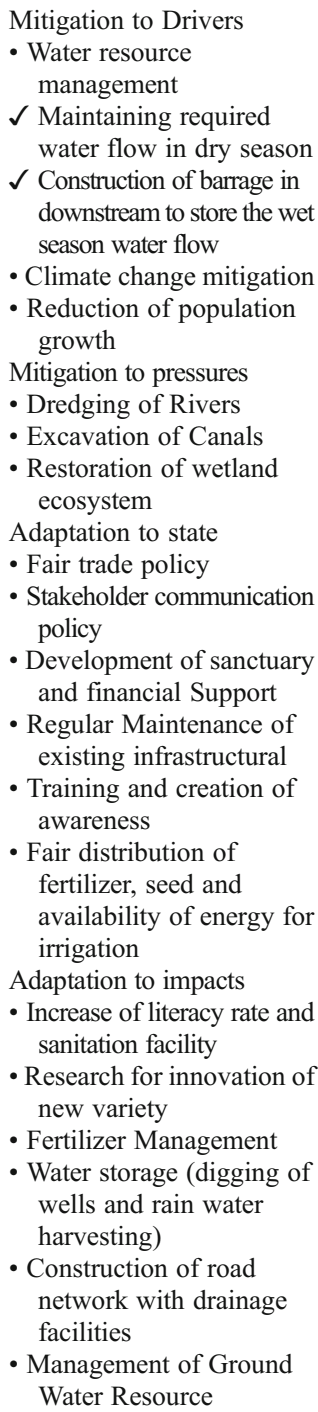 \\
\hline
\end{tabular}

mitigation responses will be in terms of responses to pressures, like dredging rivers and excavating canals. Char lands (new land created through river sedimentation) could be dredged to reduce the river erosion, particularly in Lohagora upazila. Excavation of the canals should be executed without widening the boundary. Silt obtained from the river dredging can be used as 
asset to raise the river bank and surrounding area to protect from flooding and river erosion. Community based wetland restoration, particularly the conservation of the native plants and reconnecting the wetlands and canals are recommended to enhance the water storage capacity.

Adaptive responses to changes in states can link to current vulnerability problems. For example, enhancing the water storage capacity of the water bodies, or introducing fair trade policies adjusted and monitored according to the costs of production and flood disasters in that particular year. In addition, reduction in the prices of seeds and fertilizer together with adequate supply of energy (e.g. electricity, diesel) for irrigation would help to ensure an increase the agricultural production. In this regard, replacement of electricity by solar power with increased awareness of energy-saving practices would help to provide sufficient energy for irrigation.

A policy for communicating with all stakeholders' policy is required in order to provide the guidelines for the design and implementation of development projects. For example, communities have reported not only the conflicts between indigenous fishermen groups and new migrants, but also the conflicts within existing development projects because of the lack of communication and right of access to information.

With regards the fisheries, regular monitoring and maintenance of the existing infrastructure (e.g. sluice gates) in this area are recommended rather than new physical interventions. Sanctuary development could be an important option for enhancing the fisheries production. Catching fish in the breeding months (April and May) should be prohibited, and within that period, artificially propagated local fish varieties could be released to the wetlands. Financial support for the fishermen during the prohibition period would be needed in order to promote this management programme.

Training in new techniques and raising environmental awareness can enhance the capacity of farmers and fishermen. It is known that a lack of literacy caused fishermen to provide erroneous information in the 2008 voter list, to their disadvantage. Even, the sanctuary development programme will not be successful without developing the fishermen's capacity to use different techniques.

In fact, while specific adaptation options can be recommended for coping with future impacts, the longer term ability of local communities to adapt lies with raising levels of adaptive capacity through on-going learning from the adaptation options.

A general increase of literacy will enhance the capacity of the people not only to find alternative livelihood options, but to use alternative technologies to cope with the impacts of climate change. For example, the increasing frequency of flood and water logging poses severe health risks if conventional sanitation arrangements are not replaced with newly designed sanitary latrines. Not only are regional and national research institutions needed to design new rice varieties, but they need to provide guidelines for fertilizer management and the use of organic fertilizer.

Low cost technologies like rainwater harvesting and digging wells should be offered as alternative options by which excess water in the wet season may be stored for use in the dry season. Scientific advice about the management of ground water resources through setting minimum distances between tube wells could help reduce the stresses on ground water resources. With both these options, excess water can be used as an asset for people as well as the natural ecosystems.

\section{Discussion}

Our vulnerability analyses underline the importance of addressing potential adaptation and mitigation measures at several scales. Indirect mitigation measures are available to the local 
population, for example, increasing the water holding capacity of rivers, wetlands and canals by dredging. Many other suggested responses (e.g. raising literacy; improving sanitation) are already part of on-going development processes, emphasizing the identified need (e.g. Adaptation Knowledge Platform 2013) to include adaptation responses as an integral part of regular development. Increasingly this process will have to take into account local economic policy. For example, many farmers currently suffer through the lack of a fair price for their produce, and similar situations exist for other areas of Bangladesh (e.g. IFPRI 2013). Moreover, increasing imports of rice (Reuters 2011) may be demotivating farmers in the long run, as we found among jute farmers. Extending a fair trade policy is therefore essential to maintain the livelihood of the farmers. Thus, although general mitigation and adaptation responses are recommended on the basis of stakeholder meetings, experts' interviews and national policy guidelines, the future implementation of actions will need to address the immediate social, economic and ecological conditions.

The exceptions are those mitigation measures that address large scale, international impacts. The mitigation of upstream water discharge and regional climate change is only possible through wider international control and negotiation. Yet, water discharge continues to decline even after negotiations between India and Bangladesh 1977 and 1996 sought to reconcile the resource conflict (Hossain 1998). The proposed construction of a new barrage in the downstream part of the deltaic system would help reserve water for use in dry season and also could provide 160 MW electricity (The Daily Star 2010; The Financial Express 2010; bdnews24 2010). However attractive, new initiatives would be necessary to maintain water discharge in the long term, and the current negotiation processes need to be improved in order to meet the increasing water demand in the dry season.

This study is limited to the quantification of provisioning services and has not attempted to quantify services like cultural and habitat services due to lack of data. We have overcome this limitation by using the qualitative information collected from the FGD and the quantification of provisioning services to establish the relation between ecosystem and livelihood, and these are intensively dependent on provisioning services (MA 2005). In the absence of a weather station in the study area, we analyzed the nearest weather station climate data, and we used community perceptions for mapping the spatial dimension of climatic hazards.

Our methodology could be further developed by including land use change patterns from remote sensing as a basis for understanding better the link between ES and hazards. Palaeoenvironmental records could be used to give temporal records of ecosystem processes and regulating services, like terrestrial biodiversity, water quality and soil stability (Dearing et al. 2012). Modelling of future flood extremes would significantly extend the vulnerability analysis but we have demonstrated that an integrated approach to ES and climate change provides a useful basis on which to identify adaptation and mitigation measures.

The methodology could be applied to adaptation planning and monitoring at the national level and vulnerability analysis, especially as most of previous vulnerability studies (Krishnamurthy et al. 2011a; Ahsan 2010; Krishnamurthy et al. 2011b) have not linked climate change and ES. Where ES have been considered (e.g. Metzger et al. 2006) these have been limited to land use change and farmers livelihoods. Therefore, integrated and comprehensive vulnerability analyses should become an important element in development plans.

\section{Conclusion}

Climate change, population growth and regional environmental change in the form of the Farraka Barrage are the major drivers which invoke pressures on the Narail district wetlands 
by increasing risks of flood, river bank erosion, low water availability and the changes in temperature and precipitation. The area experienced massive scale damage in floods of 1987, 1988 and 2007 yet water discharge has declined over the period 2000-2010. Declining rainfalls $(21 \mathrm{~mm} / \mathrm{season} / \mathrm{yr})$ and the increase in mean temperature $\left(0.39{ }^{\circ} \mathrm{C} / \mathrm{yr}\right)$ in the premonsoon season suggests that the dry season is has faced a growing water crisis since 1990. In contrast, the wet season has become warmer and wetter since the 1990s.

We determined 3 types of provisioning services which include 28 types of different crops, are obtained from this wetland. This ecosystem provides around 235,000 t rice, 4,000 t of fish and others, and these are the sources of income for around 30,000 farmers and fishermen contributing to the food security of $\sim 7000$ inhabitants of Narail district. Income from the provisioning services enables them to celebrate cultural festivals. The quantification of provisioning services and the qualitative assessment of social information indicate a direct and strong relationship between ES and livelihood.

Vulnerability analysis shows that within the Narail district, Lohagora upazila has the highest levels of vulnerability, particularly to river erosion and flooding. However, all three upazila are similarly exposed to hazards and particularly affected by variations in temperature and precipitation.

The GCM outputs indicate that there will be an extended and intense dry season by 2100 . Seasonal variation is likely to remain distinguishable until 2050. GCM outputs also suggest that rainfall will occur intensively in mid-monsoon and post-monsoon seasons, increasing the risk of river bank erosion and flood, whereas dry season water scarcity will increase salinity, pressures on irrigation water and a reduction in fresh water availability. The increasing temperature (up to $5{ }^{\circ} \mathrm{C}$ ) is likely to reduce crop production yield and soil health.

Mitigation and adaptation responses are interlinked with regular development activities to cope with climate and other environmental changes, but an increase in the water holding capacity of rivers, wetlands and canals by dredging is urgently required.

The modified DPSIR model in this study might be helpful for the adaptation planning and monitoring in Bangladesh, and has potential in other data-poor areas where there is a strong relationship between ES and human livelihood. It is increasingly recognized that development should incorporate ES and this methodology provides a useful means for integrating ES-based adaptation and vulnerability analysis.

Acknowledgments Sarwar Hossain acknowledges fellowship provided by the Netherlands Minister for Development Co-operation. JAD acknowledges support from the project 'Assessing Health, Livelihoods, Ecosystem Services And Poverty Alleviation In Populous Deltas (NE/J002755/1), funded with support from the Ecosystem Services for Poverty Alleviation Programme (ESPA). The UK ESPA programme is funded by the Department for International Development (DFID), the Economic and Social Research Council (ESRC) and the Natural Environment Research Council (NERC). Authors would like to thank Pip Simpson from the University of Southampton for his reviewing and commenting on the paper. More Appreciation goes to Abdul Muhit and Sopna Rani for their kind support during data collection in the study area.

\section{References}

Adaptation Knowledge Platform (2013) Adaptation or Development? Exploring the distinctions (or lack thereof) through case studies in Bangladesh and Vietnam. Stockholm Environment Institute and Regional Climate Change Adaptation Knowledge Platform, Bangkok. http://www.weADAPT.org or http:// www.asiapacificadapt.net.Cited 5th March, 2013

ADB (2003) Technical assistance to the People's Republic of Bangladesh for the Southwest Area Integrated Water Resources Management Project, Asian Development Bank. Manila. TAR: BAN 34418 
ADB (2005) Summery environmental impact assessment: South West Area Integrated Water Resources Planning and Management Project in Bangladesh. Asian Development Bank (ADB)

Ahmed M (2008) Status of common resource and future management in Chenchury Beel to support increased access and livelihoods of poor people and to maintain sustainable environment. TARATechnological Assistance for Rural Advancement, Ulashi Sreejony Sangha (USS) and Action Aid Bangladesh

Ahmed A (2011) Some of the major environmental problems relating to land use changes in the coastal areas of Bangladesh: a review. J Geogr Reg Plan 4(1):1-8

Ahsan MN (2010) Climate change and socioeconomic vulnerability: experiences and lessons from Southwestern Coastal Bangladesh. MSc. Thesis, International Development Studies, Wageningen University and Research Centre, The Netherlands

Ali MY (1997) Fish, water and people. University Press Ltd, Dhaka

Ali A (1999) Climate change impacts and adaptation assessment in Bangladesh. Clim Res 12:109-116

Andrade A, Córdoba R, Dave R, Girot P, Herrera FB, Munroe R, Oglethorpe J, Paaby P, Pramova E, Watson E, Vergar W (2011) Draft principles and guidelines for integrating ecosystem-based approaches to adaptation in project and policy design: a discussion document. IUCN- CEM, CATIE, Turrialba

Ash ACN, Ikkala N (2009) Ecosystem-based adaptation: a natural response to climate change. IUCN, Gland

Banglapedia (2011) The National Encyclopedia of Bangladesh. http://www.banglapedia.org. Cited 5th September 2011

BCAS (2006) Bangladesh wetland ecosystem- information and knowledge base. Bangladesh Centre for Advanced Studies, Dhaka

BCCSAP (2008) Bangladesh Climate Change Strategy and Action Plan. MoEF Bangladesh Ministry of Environment and Forest Government of Peoples Republic of Bangladesh

Bdnews24 (2010) Ganges Barrage construction site selected. http://bdnews24.com/details.php?id=175337\&cid=2. Cited 5th Nov 2011

Bidone ED, Lacerda LD (2004) The use of DPSIR framework to evaluate sustainability in coastal areas. Case study: Guanabara Bay basin, Rio de Janeiro, Brazil. Reg Environ Change 4:5-16

Crooks S, Herr D, Tamelander J, Laffoley D, Vandever J (2011) Mitigating Climate Change through Restoration and Management of Coastal Wetlands and Near-shore Marine Ecosystems: challenges and opportunities. Environment Department Paper 121, World Bank, Washington, DC. http://data.iucn.org/ dbtw-wpd/edocs/2011-009.pdf. Cited 20th November, 2012

Damm M (2010) Mapping social-ecological vulnerability to flooding. Graduate Research Series Phd Dissertations, United Nations University (UNU-EHS)

Dearing JA, Yang X, Dong X, Zhang E, Chen X, Langdon PG, Zhang K, Zhang W, Dawson TP (2012) Extending the timescale and range of ecosystem services through paleo environmental analyses: the example of the lower Yangtze basin. Proc Natl Acad Sci 109:E1111-E1120

DoF (2000) Fish catch statistics of Bangladesh 1998-1999. Department of Fisheries, Peoples Republic of Bangladesh Government

Hossain I (1998) Bangladesh-India relations: the Ganges water-sharing treaty and beyond, Asian affairs. An Am Rev 25(3):131-150

Hossain MS, Roy K (2010) Rainfall variability in the South-West Coastal area of Bangladesh. Proceedings 3rd International Conference on Bangladesh Environment 2010 by BEN and BAPA, Dhaka, Bangladesh, Jan 3-4 2010. Bangladesh Environmental Network (BEN) and Bangladesh Paribesh Andolon

Hossain MS, Roy K, Hauqe M, Khan HM (2010) Climate change and development: a research on mainstreaming of climate change in National Policy Development using Environmental Impact Assessment (EIA) in Water Resource Management at Narail, Bangladesh. Ulashi Sreejony Sangha (USS) and NGO Forum on ADB

Huq S, Reid H (2004) Mainstreaming adaptation in development. IDS Bull 35:15-21

IFPRI (2013) The status of food security in the feed the future zone and other regions of Bangladesh: results from the 2011-2012 Bangladesh Integrated Household Survey. International Food Policy Research Institute

IPCC (2001) Impacts, adaptation and vulnerability. Third assessment report of the intergovernmental panel on climate change. Cambridge University Press, Cambridge

IPCC (2007a) Physical science basis. Fourth assessment report of the intergovernmental panel on climate change. Cambridge University Press Cambridge, UK

IPCC (2007b) Impacts, adaptation and vulnerability. Fourth assessment report of the intergovernmental panel on climate change. Cambridge University Press, Cambridge

Islam MR (2005) Managing diverse land uses in coastal Bangladesh: Institutional approaches. Paper Presented at the International Conference on Environment and livelihoods in tropical coastal zones: managing agriculture-fishery-aquaculture conflicts, Vietnam, 2006

Islam MN, Uyeda H (2007) Use of TRMM in determining the climatic characteristics of rainfall over Bangladesh. Remote Sens Environ 108:264-276 
Islam MB, Ali MY, Amin M, Zamon SM (2011) Climatic variations: farming systems and livelihoods in the high barind tract and coastal areas of Bangladesh R. In: Lal et al. (ed) Climate Change and Food Security in South Asia, Springer

Karim Z, Hussain SG, Ahmed M (1996) Assessing impacts of climate variation on food grain production in Bangladesh.Water, Air, and Soil Pollution 92:53-62

Khan MS, SenRanjit, Noor Sh, Naser HM, Alam MK (2011) Soil, Water and Climate Related Constraints for Crop Production in Bangladesh. In: R. Lal et al. (ed)Climate Change and Food Security in South Asia, Springer Dordrecht Heidelberg New York London, pp.515-526

Krishnamurthy PK, Choularton RJ, Betts R, Lewis K (2011a) Assessing the impacts of climate risk on food security through a vulnerability index. Paper Presented in Vulnerability Workshop of GI Forum 2011, Salzburg, Austria

Krishnamurthy PK, Fisher JB, Johnson C (2011b) Mainstreaming local perceptions of hurricane risk into policy making: a case study of community GIS in Mexico. Glob Environ Chang 21(1):143-153

Kristensen P (2004) The DPSIR framework. Workshop on a comprehensive/detailed assessment of the vulnerability of water resources to environmental change in Africa using river basin approach. UNEP Headquarters, Nairobi

Lawrence P, Meigh J, Sullivan C (2002) The water poverty index: an International comparison. Keele economics research papers, www.keele.ac.uk/depts/ec/kerp. cited 1st august, 2012

Lin T, Xue X, Lu C (2007) Analysis of coastal wetland changes using the "DPSIR" model: a case study in Xiamen, China. Coast Manag 35:289-303

Luers A, Lobell DB, Sklar LS, Addams CL, Matson PA (2003) A method for quantifying vulnerability, applied to the agricultural system of the Yaqui Valley Mexico. Glob Environ Chang 13:255-267

MA (2005) Millennium ecosystem assessment, ecosystems and human well-being: a framework for assessment. Island Press, 1-25

Mangi SC, Roberts CM, Rodwell LD (2007) Reef fisheries management in Kenya: preliminary approach using the driver-pressure-state-impacts-response (DPSIR) scheme of indicators. Ocean Coast Manag 50:463-480

Maplecroft (2010) Big economies of the future - Bangladesh, India, Philippines, Vietnam and Pakistan - most at risk from climate change, 21 st October, 2010. http://maplecroft.com/about/news/ccvi.html. Cited 20th September, 2012

Metzger MJ, Rounsevell MDA, Acosta-Michlik L, Leemans R, Schröter D (2006) The vulnerability of ecosystem services to land use change. Agriculture, Ecosystems and Environment 114:69-85

Moni AH, Hossain MS (2010) Response of environmental changes (Climate) in wetlands. Proceedings 3rd International Conference on Bangladesh Environment 2010 by BEN and BAPA, Dhaka, Bangladesh, 2010. Bangladesh Environmental Network (BEN) and Bangladesh Paribesh Andolon

Mysiak J, Giupponi C, Rosato P (2005) Towards the development of a decision support system for water resource management. Environ Model Softw 20(2):203-214

NAPA (2005) Bangladesh National Adaptation Program of Action. MoEF Bangladesh Ministry of Environment and Forest Government of Peoples Republic of Bangladesh

OECD (2009) Integrating climate change adaptation into development co-operation: policy guideline. Organization for Economic Co-operation and Development

Ojeda-Martínez C, Casalduero FG, Bayle-Sempere JT, Cebrián CB, Valle C, Sanchez-Lizaso JL, Forcada A, Sanchez-Jerez P, Martín-Sosa P, Falcón JM, Salas F, Graziano M, Chemello R, Stobart B, Cartagena P, Pérez-Ruzafa A, Vandeperre F, Rochel E, Planes S, Brito A (2009) A conceptual framework for the integral management of marine protected areas. Ocean Coas Manag 52:89-101

Rahman MM, Islam MA (2005) Better options for IFM: uptake promotion NRSP project R8306 final technical report: annex a. Center for Natural Resource Studies (CNRS), Dhaka

Rao NS, Carruthers TJB, Anderson P, Sivo L, Saxby T, Durbin T, Jungblut V, Hills T, Chape S (2012) A comparative analysis of ecosystem-based adaptation and engineering options for Lami Town, Fiji. A synthesis report by the Secretariat of the Pacifi c Regional Environment Programme

Reuters (2011) 2-Bangladesh 2010/11 grain import to hit record $5.5 \mathrm{mln}$ T', 3rd June. http://in.reuters.com/ article/2011/06/03/bangladesh-grain-importidINL3E7H30UH20110603. Cited 5th December 2011

Roy K, Rahman M, Kumar U (2009) Future climate change and moisture stress: impact on crop agriculture in South-Western Bangladesh. Scientific Briefing series of Unnayan Onneshan, Dhaka Bangladesh

Saadat MA, Islam, AKMS (2011) Impact of climate change on rural livelihood: a case study. Paper presented at the International Conference on Water \& Flood Management (ICWFM-2011), Dhaka, Bangladesh

Schipper ELF (2007) Climate Change adaptation and development: exploring the linkages. Tyndall Centre Working Paper No.107, Tyndall Centre for Climate Change Research, School of Environmental Sciences, University of East Anglia, UK 
Sekovski I, Newton A, Dennison WC (2012) Megacities in the coastal zone: using a driver-pressure-stateimpact-response framework to address complex environmental problems. Estuarine Coastal Shelf Sci 96:48-59

The Daily Star (2010) Ganges barrage work from 2012. 6th Oct, 2010. http:/www.thedailystar.net/newDesign/ news-details.php?nid=157349. Cited 5th Nov 2011

The Financial Express (2010) construction of ganges barrage begins in 2012. Vol 22 (27), 11th July 2011

UNEP (2009) The role of ecosystem management in climate change adaptation and disaster risk reduction. Copenhagen discussion series, United Nations Environmental Program (UNEP)

Vignola R, Locatelli B, Martinez C, Imbach P (2009) Ecosystem-based adaptation to climate change: what role for policy-makers, society and scientists? Mitig Adapt Strateg Glob Change 14:691-696

WB (2000) Bangladesh: climate change \& sustainable development. Report no.21104 BD. World Bank (WB), Dhaka

Wertz-Kanounnikoff S, Locatelli B, Wunder S, Brockhaus M (2011) Ecosystem-based adaptation to climate change: what scope for payments for environmental services? Climate Dev 3(2):143-158 